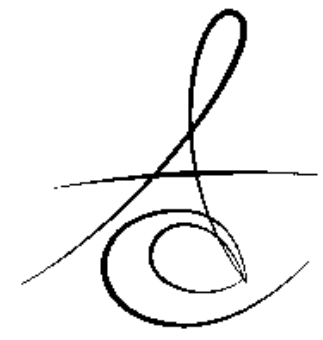

\title{
CALCIFYING EPITHELIAL ODONTOGENIC TUMOR (PINDBORG TUMOR): A CASE REPORT
}

\section{KALSIFİYE EPITTELYAL ODONTOJENIK TÜMÖR (PINDBORG TÜMÖRÜ) : BİR OLGU RAPORU}

Dt. Suzan BAYER*

Doç. Dr. Ahmet MIHMANLI*

\author{
Dt. Nihat DEMIRTAŞ* \\ Prof. Dr. Fatma Canan ALATLI**
}

Makale Kodu/Article code: 2067

Makale Gönderilme tarihi: 15.01 .2015

Kabul Tarihi: 03.04.2015

\section{ÖZET}

Kalsifiye epitelyal odontojenik tümör, diş gelişimi sırasında epitelyal, ektomezenkimal ve/veya mezenkimal hücrelerden oluşabilen iyi huylu bir lezyondır. Tüm odontojenik tumörlerin yaklaşık \%1'lik bölümünü oluşturur ve çoğu zaman sürmemiş dişlerle birlikte görülür. Klinik olarak lokal invazyonla birlikte yavaş büyüyen, asemptomatik ve nüks potansiyeli olan lezyonlardır. Bu tümörler bazen kötü huylu lezyonlarla karıştırılabilir. Kesin tanı histopatolojik muayene ile konulur.

$\mathrm{Bu}$ makalede, 42 yaşında bir erkek hastanın üst çenesinde tespit edilen tek taraflı CEOT olgusu rapor edildi. Rutin panaromik radyografta teşhis edilen lezyon, konservatif bir cerrahi eksizyon ve küretaj ile tedavi edilmiştir. On sekiz aylık takip sonucunda da herhangi bir nüks gözlenmemiştir. Özetle bu makalede, literature katkı sağlamak ve kalsifiye epitelyal odontojenik tümörlerin klinik, radyolojik ve histopatolojik özellikleri hakkında klinisyenleri bilgilendirmek amaçlandı.

Anahtar Kelimeler: Kalsifiye epitelyal odontojenik tümör, üst çene, gömülü diş, enükleasyon

\section{INTRODUCTION}

Calcified epithelial odontogenic tumor (CEOT) is a rare benign neoplasm of the jaws which occurs generally in adult patients. Jens Jorgen Pindborg was firstly reported this entity in $1955 .{ }^{1}$ For this reason, it is also called "Pindborg Tumor". Two different types of CEOT is described as intraosseous (central) and extraosseous (peripheral) forms. ${ }^{2}$ The extraosseous

\section{ABSTRACT}

Calcifying epithelial odontogenic tumor (CEOT) are rare benign lesions derived from epithelial, ectomesenchymal and/or mesenchymal elements .It accounts for less than $1 \%$ of all odontogenic tumors and generally related with an impacted tooth. Clinically, they are slow-growing tumors with local invasion, asymptomatic and have a risk of reccurrence. However, these lesions are occasionaly confused with malignant lesions. The final diagnosis is made by the histopathological examination.

Here, we report a case of 42 - year old male patient with unilateral CEOT in the maxilla. The lesion which was detected on routine panoramic radiography treated with conservative surgical excision and curettage. There has been no sign of recurrence 18 months after surgery. In conclusion, this paper aims to contribute to the literature and inform the clinicians about clinical, radiological, histopathological features and surgical treatment of CEOTs.

Keywords: Calcifying Epithelial Odontogenic Tumor, maxilla, impacted tooth, enucleation

variant has a strong predilection for anterior gingiva. Intraosseous lesions are more common type and they are mostly seen in the mandible posterior region. In addition, more than half of these lesions are associated with an impacted tooth. ${ }^{3}$ In many cases, CEOT occur in the fourth and fifth decades of life and it affects both sexes equally. ${ }^{4}$

These tumors have varied presentation and are often mixed with a variety of malignant lesions. ${ }^{5}$ However, malignant transformation and metasthasis

*Department of Oral and Maxillofacial Surgery, Faculty of Dentistry, BezmialemVakif University

**Department of Oral Patology, Faculty of Dentistry, IstanbulUniversity 
Atatürk Üniv. Diş Hek. Fak. Derg.

J Dent Fac Atatürk Uni

Supplement: 13, Yll: 2015, Sayfa : 42-46

have been reported in the literature. ${ }^{6}$ Hence, early treatment and diagnosis of these lesions is extremely important in oral surgery practice because of many risk factors.

The objective of this report is to highlight the clinical, radiological and histopathological features of CEOTs. In addition, we aimed to discuss the details of the surgical treatment options.

\section{CASE REPORT}

A 42- year-old male patient visited the Department of Oral and Maxillofacial Surgery with chief complaint of painless swelling in the right side of his upper jaw. The patient was healthy and had no history of any regular medications. However, he presented a history of tooth extraction of the upper molars two years ago. On extraoral inspection, we did not detect any abnormalities (Figure 1a). The intraoral examination showed painless gingival mass resembling in the edantolous arch (Figure $1 \mathrm{~b}$ ). Beside, the patient had poor oral hygen and periodontal disease (Figure 1c, d).

The panoramic radiography revealed a large well-bordered radiolucent area related with an impacted third molar in the right maxillary posterior region (Figure 1e). Dental volumetric computed tomography (DVCT) scan showed a large destructive lesion with alveolar bone resorption (Figure $2 \mathrm{a}, \mathrm{b}$ ). In addition, the localization of the impacted tooth and tumoral calcifi cations were observed on frontal and coronal sections of the DVCT (Figure $2 \mathrm{c}, \mathrm{d}$ ).

An incisional biopsy was done under local anesthesia. The microscopic features of the specimen included pleomorphic epithelial tumor cells with amiloid material. Hence, histopathologic diagnosis of CEOT was made. (Figure $3 a, b, c$ ).

The lesion was treated with conservative surgical excision and curettage under general anesthesia. It was dissected carefully and all internal surfaces of the maxillary sinus was observed after enucleation (Figure $4 a, b$ ). The healing period was uneventful. Postoperatively, a control radiography was obtained to determine surgical site (Figure 4c). Eighteen months after surgery, the control radiography and intraoral examination showed that the patient is asymptomatic and recurrence-free (Figure $5 a, b$ ).
BAYER, DEMİRTAŞ, MIHMANLI, ALATLI
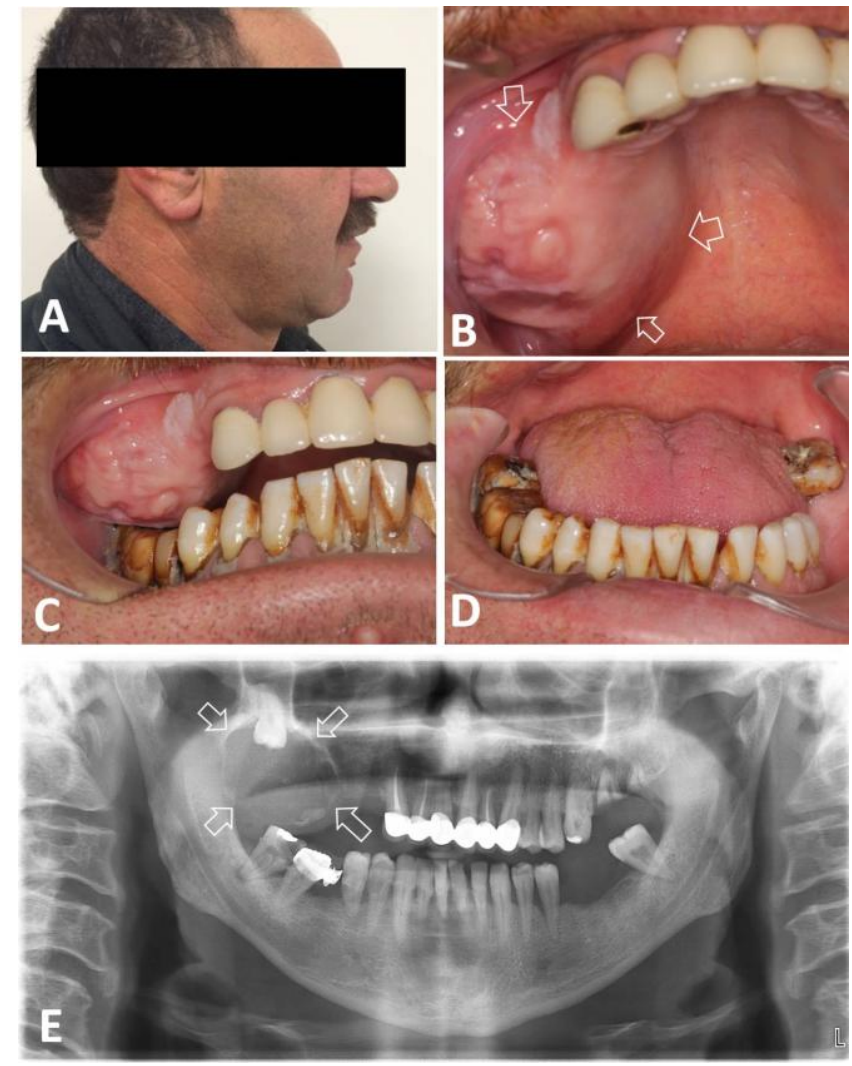

Figure 1. Clinical and radiological presentation; (A) extraoral view of the patient (B) swelling mass (white arrows) on the right molar region in the maxilla $(C, D)$ occlusal relationship and lower teeth; clinically, poor oral hygiene was observed. (E) Panoramic radiography of the patient, white arrows show the lesion.

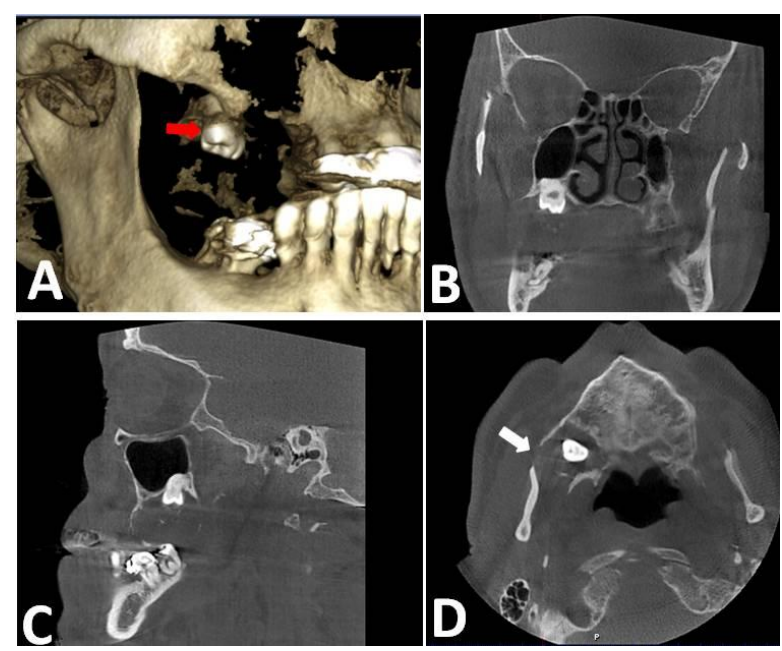

Figure 2 . DVCT Scans of the patient. (A) 3-D reconstrucion views the impacted tooth and bone resorption (red arrow), $(B, C)$ Coronal and sagittal section shows the mass with buccal and palatinal bone loss and localization of the tooth (D) Axial section shows the buccal cortical destruction

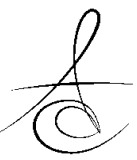



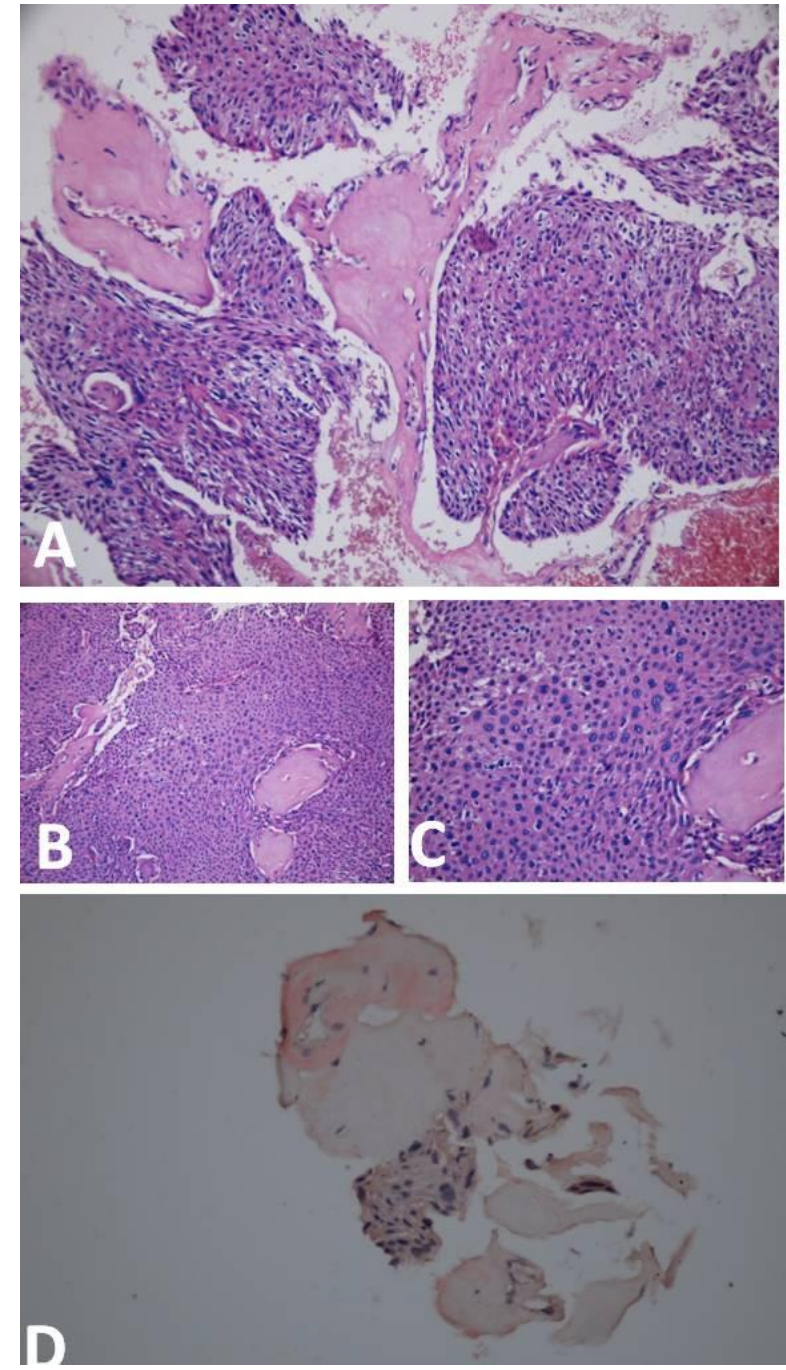

Figure 3. (A) Microscopic appearance of CEOT reveals sheaths and groups of epithelial cells with large, eosinophilic cytoplasm, close to hyalinised connective tissue (Hematoxylene\&Eosine, $x$ 100). (B) Pleomorphic epithelial tumor cells can be observed in CEOT (B- Hematoxylene\& Eosine, $x$ 200) (C) Hematoxylene\&Eosine, x 400). (D) Small areas of amiloid material, staining positively with Congo Red stain, could be seen in the hyalinised connective tissue, in the neighbourhood of epithelial tumor cells (Congo Red, $\mathrm{x} 400)$.

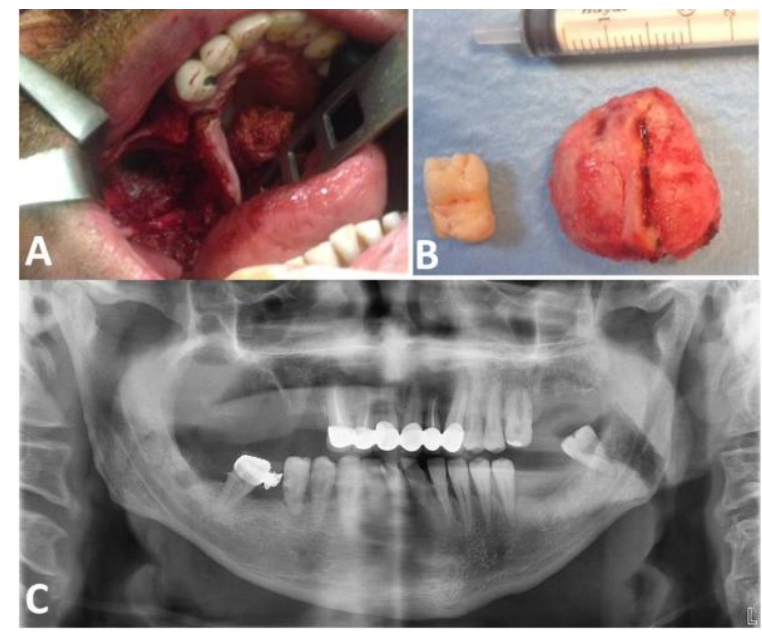

Figure 4 . (A) Surgical site after the enucleation of the tumor, (B) The tumor specimen and extracted tooth , (C) Postoperative control radiography

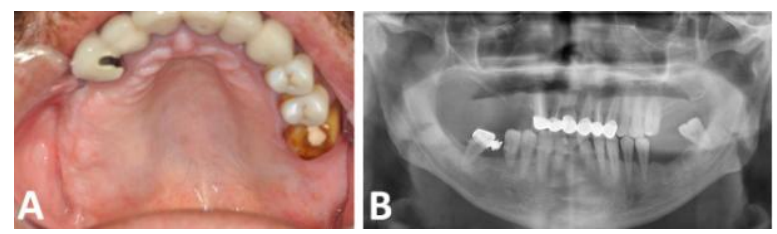

Figure 5. Intraoral view (A) and panoramic radiography (B) of the patient eighteen months after surgery; it seems that the healing process of the alveolar crest is completed and there are no sign of recurrence.

\section{DISCUSSION}

Odontogenic tumors are derived from epithelial, ectomesenchymal or mesenchymal elements from the tooth-forming apparatus. ${ }^{7}$ CEOTs are account for less than $1 \%$ of all odontogenic tumors. ${ }^{3-6}$ On average, two-thirds of these neoplasms occur in the mandible and generally located in the posterior region. Thus, maxillary lesions are rare. In many cases, CEOTs has association with impacted teeth. ${ }^{8}$ Bouckaert et al. ${ }^{9}$ reported that CEOTs can cause epistaxis, nasal stuffiness, proptosis and headache when they located in the maxilla. Reported presenting with abnormal eye signs due to giant Pindborg tumor in the maxilla ${ }^{10}$. The case presented here, the tumor identified in the maxillary sinus area but it was asymptomatic. On the other hand, expansion of lateral wall of the nose and buccal cortical bone were observed.

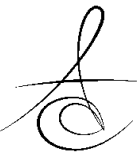


Atatürk Üniv. Diş Hek. Fak. Derg.

J Dent Fac Atatürk Uni

Supplement: 13, YIl: 2015, Sayfa : 42-46
BAYER, DEMİRTAŞ, MIHMANLI, ALATLI
There are specific radiographic features that may help the clinician for diagnosis of these tumors. Kaplan et al. ${ }^{11}$ reported that CEOTs have mixed radiolucent- radiopaque pattern with diffuse borders on the radiography. In addition, they reported root resorption in \%4 of 67 cases. Beside, the radiographic views may include unilocular and/or multilocular radiolucent areas similar to a dentigerous cyst or ameloblastoma. ${ }^{12}$ In many cases, bicortical expansion and destructive process due to bone resorption are reported..$^{9-10}$ The case presented here, the lesion had well-bordered appreance without bone resorption on panoramic radiography.

Histologically, the lesions include squamous cell proliferation, calcified rings, and amyloid or amyloidlike deposits. ${ }^{13}$ The differential diagnosis includes adenomatoid odontogenic tumor, calcifying odontogenic cyst, dentigerous cyst, ameloblastic fibroodontoma and odontoma. The case presented here, sheaths and groups of epithelial cells with large, eosinophilic cytoplasm, close to hyalinised connective tissue were observed as a characteristic features of CEOTs. In addition amiloid material and hyalinised connective tissue, in the neighbourhood of epithelial tumor cells were identified with Congo Red stain.

The method of treatment is based on the size and anatomic of the lesion. Threatment of maxillary lesions usually include maxillectomy, since they grow rapidly, occur in vicinity of important structures (orbit, skullbase) and do not remain confined. Moreover, recurrence (14\%) occurs more frequently in maxilla than mandible. Enucleation with curettage is not recommended because they have high reccurrence rate. $^{12}$ On the other hand, the majority of authors agree that $1 \mathrm{~cm}$ safety margin is sufficient especially for mandible ${ }^{12,14}$. In the present case taking into account the possibility of development a residual bone defect, we decided to perform conservative treatment, nucleation with local curettage under general anaesthesia. After eighteen mouths follow-up period, there was no clinical evidence of recurrence of the lesion. The patient will be periodically examined over the next five years to verify the possible recurrence of the lesion.

Tabangay et al. ${ }^{12}$ reported CEOTs' reccurrence rate between 10 to $15 \%$.Kawano et al. ${ }^{15}$ described a case of CEOT of the mandible with malignant transformation and development of metastasis of the lung after repeated local recurrence. However, risk of malignant transformation is low. In our case, malignant transformation has not been occured in the control period.

\section{CONCLUSION}

In conclusion, CEOT is a rare lesion and there are no large series of patient with long-term follow up. We belive that early diagnosis and conservative tretment is extremly important in the managent of CEOTs.

\section{REFERENCES}

1. Pindborg JJ. Calcifying epithelial odontogenic tumour. Acta Pathol Microbiol Scand 1955;111:71.

2. El-Labban NG. Cementum-like material in a case of Pindborg tumor. J Oral Pathol Med. 1990;19:1669.

3. Bridle C, Visram K, Piper K, Ali N. Maxillary calcifying epithelial odontogenic (Pindborg) tumor presenting with abnormal eye signs: Case report and literature review. Oral Surg Oral Med Oral Pathol Oral Radiol Endod 2006; 102: 12 - 5.

4. Singh N, Sahai $S$, Singh S. Calcifying epithelial odontogenic tumor (Pindborg tumor) Natl J Maxillofac Surg. 2011; 2: 225-7.

5. Cheng YS, Wright, JM, Walstad WR, Finn MD. Calcifying epithelial odontogenic tumor showing microscopic features of potential malignant behavior. Oral Surg Oral Med Oral Pathol Oral Radiol Endod. 2002; 93: 287-95

6. Veness MJ, Morgan G, Collins AP, Walker DM. Calcifying epithelial odontogenic (Pindborg) tumor with malignant transformation and metastatic spread. Head Neck 2001;23:692.

7. Özan F, Yeler H, Göze ÖF. Parakeratotik Tip Odontojenik Keratokist: Vaka Raporu. Atatürk Üniv Diş Hek Fak Derg. 2006; 1: 81-4

8. Rapidis $A D$, Stavrianos $S D$, Andressakis $D$, Lagogiannis G, Bertin PM. Calcifying epithelial odontogenic tumor (CEOT) of the mandible: Clinical therapeutic conference. J Oral Maxillofac Surg. 2005;63:1337-47. 
9. Bouckaert MM, Raubenheimer EJ, Jacob FJ. Calcifying epithelial odontogenic tumor with intracranial extension: Report of a case and review of the literature. Oral Surg Oral Med Oral Pathol Oral Radiol Endod. 2000;90:656-62.

10. Bridle C, Visram K, Piper K, Ali N. Maxillary calcifying epithelial odontogenic (Pindborg) tumor presenting with abnormal eye signs: case report and literature review. Oral Surg Oral Med Oral Pathol Oral Radiol Endod. 2006;102:12-5.

11. Kaplan I, Buchner A, Calderon S, Kaffe I.Radiological and clinical features of calcifying epithelial odontogenic tumour. Dentomaxillofac Radiol. 2001; 30:22-8.

12. Tabangay-Lim IM, Mallari RN, Lacsamana NM, Paz DDZ, Villafuerte ARR, Quilendrino PRM. Recurrent calcifying epithelial odontogenic tumor (Pindborg tumor): A case study. Oral Oncology Extra 2005; 41: 259-66.

13. Aviel-Ronen S, Liokumovich P, Rahima D, PolakCharcon S, Goldberg I, Horowitz A. The amyloid deposit in calcifying epithelial odontogenic tumor is immunoreactive for cytokeratins. Arch Pathol Lab Med. 2000; 124:872-6.

14. Hada MS, Sable M, Kane SV, Pai PS, Juvekar SI. Calcifying epithelial odontogenic tumor: A clinicoradio-pathological dilemma. Journal of Cancer Research and Therapeuties . 2014; 10: 194-6.

15. Kawano K, Ono K, Yada N, Takahashi Y, Kashima K, Yokoyama S, Yanasıgawa S. Malignant calcifying epithelial odontogenic tumor of the mandible: report of a case with pulmonary metastasis showing remarkable response to platinum derivatives. Oral Surg Oral Med Oral Pathol Oral Radiol Endod. 2007; 104: 76-81.

\author{
Yazışma Adresi \\ Dt. Suzan Bayer \\ Bezmialem Vakıf Üniversitesi \\ Diş Hekimliği Fakültesi, \\ Ağız Diş ve Çene Cerrahisi Anabilim Dalı. \\ 34093-İSTANBUL \\ Tel: +902124531700 \\ Faks: +90 2125332326 \\ E-posta:suzanbayer@gmail.com
}

